and almost the only available for house-building in the deserts of the south-west-and the palo verde (Parkinsonia microphylla), which, according to soil and water supply, varies from 3 feet to 15 feet in height-these and the many other characteristic xerophytes become very real to us from Mr. Hornaday's quite non-technical descriptions and the photographs taken by one or other of the party.

The author is also a sportsman, and the text has many interludes which will interest the sportsman rather than the botanist; and it would be unfair not to mention the numerous observations on animal-life, especially the valuable chapter on the mountain sheep of Mexico and the range of the species. be seen, but gallant attempts were made to reach them, as is duly recorded in Cav. De Filippi's narrative. Most of the expeditions added materially to our knowledge, and the repeated failures to achieve complete success tempted the Duke of the Abruzzi to undertake the exploration of Ruwenzori. He organised an expedition on a royal scale, judiciously selected the most favourable time of year, and the easy route by the Uganda Railway and steamer across the Victoria Nyanza. He left Entebbe, the capital of Uganda, on May 14, 1906, at the head of a caravan of 400 men, including a distinguished scientific staff, a company of Swiss guides and porters, and the great

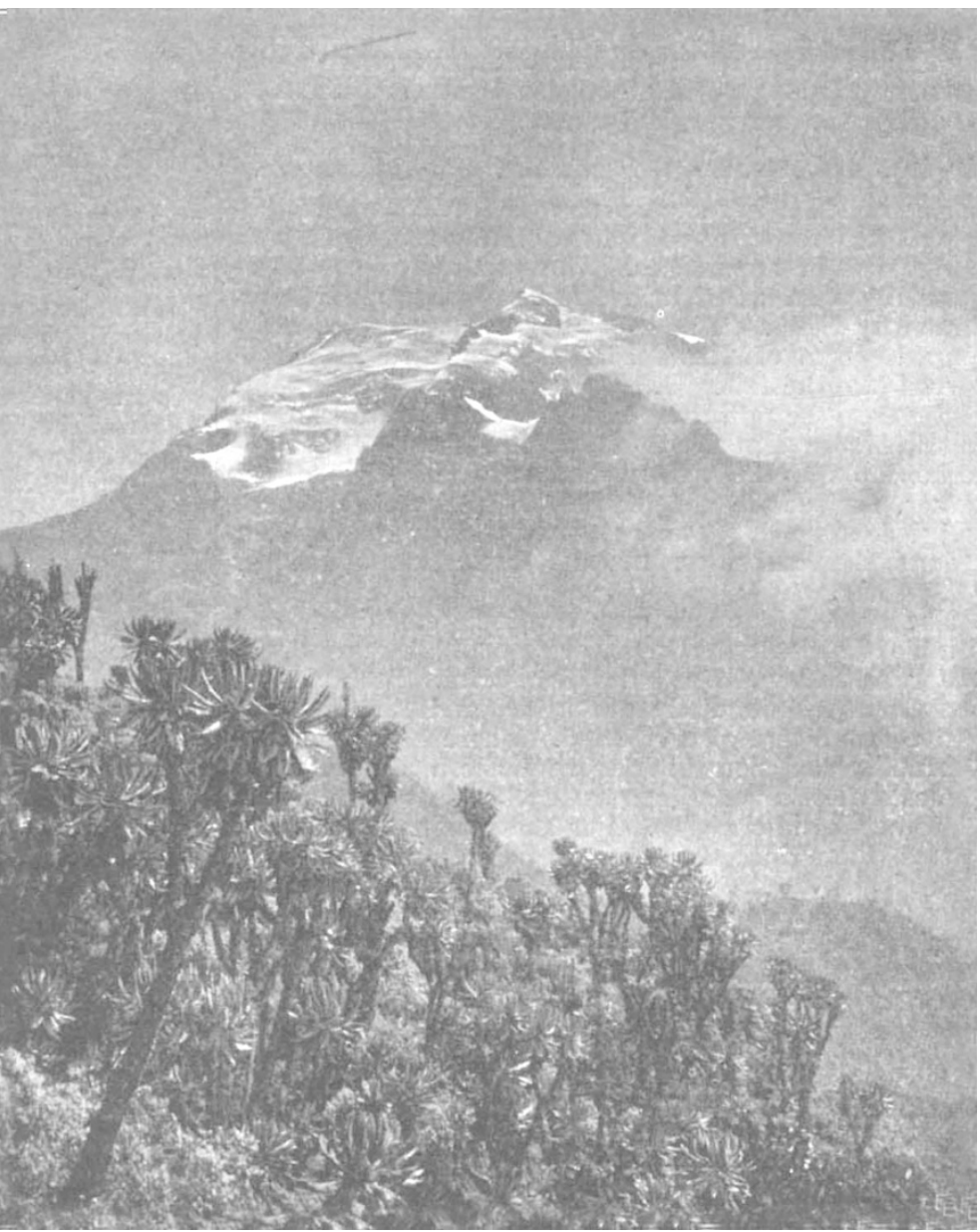

Mount Speke seen from the Senecio Forest at the foot of Scott Elliot's Col. From "Ruwenzori." plored. Stühlmann passed along its western side and took some fine photographs of the snow-capped peaks. Scott Elliot entered the range, saw some of its glaciers, and discovered that they were formerly more extensive. His observations and collections showed that instead of Ruwenzori having been volcanic, as had been suggested from analogy with Kilimanjaro and Kenya, it is a tilted block of Archean rocks left upstanding between the Victoria Nyanza basin and the rift valley of the Semliki. The later expeditions that visited the mountain found it usually shrouded in the clouds that had hidden it from Stanley's predecessor, Baker. The peaks could seldom

1 "Ruwenzori : an Account of the Expedition of H.R.H. Prince Luigi Amedeo of Savoy, Duke of the Abruzzi." By F. de Filippi. Pp. xvi 408 ; illustrations. plates, 5 maps. With a preface by H.R. H. the Duke of the
Abruzzi. (London: A. Constable and Co., Ltd., 1908.) Price $31 s .6 d$. net. mountain photographer, Sella. Aided by the British officials, to whom warm thanks are expressed in the book, the Duke of the Abruzzi soon reached the eastern foot of the mountains, and established a light camp near the head of the valley, up which most of his predecessors had climbed to the Alpine regions of Ruwenzori. 'The expedition had been carefully equipped, and its resources were handled with the Duke's usual energy and courage. He overcame all obstacles, climbed all five of the ice-capped mountains, and most of the chief peaks; and his expedition returned with a series of mountain photographs unrivalled in African literature, a geological map of the main part of Ruwenzori, and detailed information as to its geography.

No. 2062, voL. 80] 
The history of the expedition has been compiled by Cav. De Filippi, and it is clear from his narrative that the expedition required great personal strength, courage, and endurance. The Prince and his two guides were badly smitten with snow blindness after the ascent of Mount Stanley, for they had to work all day in a glaring white fog, which was too dense to allow the use of goggles. The author mentions (p. 243) that the Prince spent seventeen days above the height of 13,000 feet, with a very light equipment, sleeping with the two guides in a Whymper tent, without a camp bed, and with clothes nearly always soaked with rain and snow. The climbing was in places very difficult, and the dangers were increased by the prevailing mists and bad weather. Some of the ascents taxed the skill of such expert climbers as the Prince and his two guides; but others were easy; thus the highest point of Mount Speke, I6,080 feet, though snow covered, did not require the use of the rope.

Commander Cagni, the surveyor of the expedition, has compiled a full sketch-map of Ruwenzori, including all its snow-covered peaks. The topographic data are stated in appendices. The mountains are illustrated by a series of magnificent photographic panoramas by Sella. The survey shows that the snowcapped peaks of Ruwenzori are arranged in a line curved like the letter G. Going from the upper point of the $G$ to the tail, the peaks in succession are Mount Gessi, Mount Emin, Mount Speke, Mount Stanleywhich includes the highest peaks of the ridge-Mount Baker, and at the end of the tail of the $G$ is Mount Luigi de Savoia. The height of the highest point, Mount Margherita on Mount Stanley, is given as I6,8 15 feet.

The nomenclature is very carefully explained, and a table of synonyms (pp. 218-9) will be useful, as geographers are above rules of priority. Stühlmann's early names are quietly put aside, and the proposed native names are also rejected. There had been considerable confusion in the application of the early names, but this is perhaps hardly likely to be removed by some of the changes. For the worst alteration of names, the Prince, however, is not responsible, as he only yielded to the wish of the Geographical Society. It naturally desired that the Prince's name should be attached to one of five mountains, but unfortunately selected the one that had been named Mount Moebius by Stühlmann years earlier. The name Moebius has, therefore, been transferred to a minor peak in the central part of the range. The peaks called by Stühlmann Mount Semper are re-christened the Alexandra and Margherita peaks of Mount Stanley.

The full scientific results are being published in a supplementary volume which has not been translated, but some account of the results is included. The geological collections and geological sketch-map of the central part of Ruwenzori fully confirm the Archean age of its rocks, as to which doubt had been suggested by Mr. Wollaston's description of craters and craterlakes; the author refers to some veins of basalt in the gneiss (p. 222) as the only formation on Ruwenzori of a volcanic nature, and such veins do not necessarily indicate volcanic action. The glaciers are proved to be ice-caps or calottes, with the glaciers extending as finger-shaped processes. The snow limit is at present at the height of from 14,700 to 14,800 feet, but it is now suggested that the glaciers extended even lower than was claimed by Scott Elliot. The evidence on which this low-level glaciation is based is, however, not given, and some doubt as to its value is raised by the remark that the exfoliation surfaces of

$$
\text { NO. 2062, VOL. 80] }
$$

granite, the characteristic weathering of granite in the tropics, are "somewhat similar to the rocks. known as moutonnées in regions which have passed through a glacial period" (p. 9l). However, as the rainfall in Ruwenzori is probably exceptionally heavy, it may well be that the glaciers there reached a lower level than on Mount Kenya. All students of African geography, and all interested in mountain exploration, will feel indebted to the Duke of the Abruzzi for the brilliant feat of travel by which he has wrested from the clouds of Ruwenzori the secrets they have concealed so long.

J. W. Gregory.

\section{SOME ASPECTS OF THE WHEAT PROBLEM.}

$\mathrm{F} E W$ agricultural problems appeal to a wider circle both among agriculturists and the general public than wheat production; the layman often considers it to be the farmer's chief business, and many farmers are still to be found who look back with regret on the days when it actually was so.

The area under wheat in the whole world exceeds 200 million acres, and something like 400 million quarters are raised. About 220 million quarters are grown in Europe, Russia being the chief producer, followed by France, Hungary, and Italy; I07 million quarters are grown on the American continent (more than 75 million in the United States, 20 million in the Argentine, and ro million in Canada), and about 53 million quarters in Asia, three-fourths of which comes from India. It is noteworthy that the wheat area tends to decrease in old and highly farmed countries, but to expand in new countries or in old, backward countries just beginning to utilise their resources. To a certain extent, wheat is, therefore, a pioneer crop, and is relatively more important in the early stages of development of a country than later on when it simply takes its place in the rotation with other crops. It cannot remain so indefinitely, but there are still immense tracts to which it can spread. It requires warm, sunny summers, and not too much rain; indeed, it can do with astonishingly little rain if appropriate cultivation methods are adopted; where the summers are suitable, severe winters are no bar to the cultivation of wheat, though they may limit the yield.

The fact that wheat is one of the first crops grown in a new country renders necessary a thorough study of the effect of external conditions such as soil, climate, and manuring on its development. Much still remains to be done, especially with regard to the influence of water supply. There are also important breeding problems. No crop can be successfully grown on a large scale unless it is adapted to the local conditions, tolerably resistant to the local diseases, and commands an adequate price in the market. The first two conditions afford fairly straightforward problems. Wheats suitable to a given district are usually found by trying a number of varieties, and then improving on the most promising by the slow and mechanical process of selection-in other words, waiting for a " mutation" form to turn up. Resistance to rust, one of the worst diseases of wheat, has been shown by Biffen to be in all probability a Mendelian character; it should, therefore,

1 A. E. Humphries: Journal of the Royal Soclety of Arts, No. 2934 ; A. Howard and G. L. C. Howard: Bulletin 14, Agricultural Research Institute, Pusa ; A. E. V. Richardson: Journal of Agriculture of South Australia, vol. xii., No. 6 ; K. J. J. Mackenzie: Journal of the Board of Agriculture, vol. xv., No. Io. 